\title{
New forms of government and the europenisation of minority representation: the case of European Roma
}

\author{
Ionuţ-Marian Anghel \\ School for Advanced Studies at the Romanian Academy/Research Institute for Quality of Life1 \\ ionutanghel7@gmail.com
}

\begin{abstract}
The situation of roma since the fall of socialism is a paradox. On the one hand, many organizations, international governing organizations (IGOs), such as the European Union (Council of Europe, European Commission, European Parliament), the Organization for Security and Cooperation in Europe, the World Bank and the United Nations (UNDP, UNICEF, ILO), local and international/transnational NGOs, government agencies are involved in projects for Roma to improve their situation in Europe. Roma have become the target of social inclusion programs of the European Union (EU), the Decade of Roma Inclusion - a project of the Open Society Foundation and the World Bank -, Strategies for improving the situation of Roma developed by governments in Southeastern Europe. On the other hand, Roma continue to be marginalized, discriminated against, politically underrepresented, with a higher probability of being unemployed, not having access to public services education, health , housing - compared with the majority population. This paper seeks to understand how was it possible to understand the recent shift from the representation of the Roma as a non-European minority, which lasted since their arrival in Europe until the fall of socialist regimes, to their representation as an European minority as it is shown in documents of the European institutions and the World Bank? How did Roma appear on the EU social inclusion agenda, the Human Development agenda of UNDP or the minority rights agenda of OSCE?
\end{abstract}

Keywords: roma, minority representation, governance

\section{Introduction}

Today, Roma are presented uncritically in EU's policy documents, inter-governmental organizations (IGOs) (such as Council of Europe, Organization for Security and Cooperation in Europe, European Union) development agencies (UNDP and World Bank), and national governmental documents, in an ambivalent way, as a 'European problem', 'vulnerable group' or 'European minority' (CoE 1993a; EC 2011; EU 2003; Liégeois \& Gheorghe 1995; McGarry 2008; McGarry 2011a; McGarry 2011b; Mirga \& Gheorghe 1997; Ringold 2000; Ringold et al. 2005; UNDP 2002; UNDP 2006). The Europeanization of various heterogeneous Romani groups has marked a significant shift in the political approach towards Roma. Indeed, if during the Enlightenment, the processes of nation-state building and under communism, the Roma was considered a non-European, as alien and barriers to civilization and progress, after 1989, the Roma and their identity have been Europeanized (van Baar 2011b). The Europeanization of Romani representation did not remain only at the IGO's level. Mass-media, Romani activists, pro and Romani non-governmental organizations and academics have all presented the Roma as a European minority. Recently, the Socialist \& Democrats Party in the European Parliament has published a book, entitled 'Roma: A European Minority' (Flasikova-Benova et al. 2011). Due to constant pressure from advocacy groups and Romani activists and NGOs, the European Parliament has asked the European Commission through a number of resolutions (EP 2005; EP 2008) to put forward a European Framework for the National Roma Integration Strategies (EC 2011).

I do not want to suggest that responsibility for the inclusion of Roma has shifted upwards towards European institutions, neither that the IGOs have been the only organizations that were involved in projects and policies aimed towards the improvement of the situation of Roma. National governments and local/national/transnational NGOs have implemented policies which benefitted Roma. What I will try to argue in this paper, -using analysis of policy documents - is why this recent involvement of various IGOs and NGOs in a common effort to 'turn the tide' for the benefit of Roma. If large scale programs aren't new in Europe -we have witnessed such programs since the end of $18^{\text {th }}$ century and during state socialism - what is truly new after 1989 is this European effort to actively include the Roma in the programs devised for them (van Baar 2011a). So, the paper is split in three parts in which, I present a short history of the IGOs implication in Roma affairs, its rationale and the recent shift in new forms of governance aimed at improving the public and social policies

1 This paper is made and published under the aegis of the Research Institute for Quality of Life, Romanian Academy as a part of programme co-funded by the European Union within the Operational Sectorial Programme for Human Resources Development through the project for Pluri and interdisciplinary in doctoral and post-doctoral programmes Project Code: POSDRU/159/1.5/S/141086 


\section{Europenization and new tools of minority governance}

The fall of socialism and the transition from planned to market economy has had significant consequences for the Roma population in the region. Deindustrialization, the abolition of collective farms and state enterprises - where they were mainly employed - has led to increased unemployment among Roma, being among the first laid off in these sectors. Without a steady source of income, the declining standard of living and the raising costs of crucial public services - such as education and health - all affected more the Roma for whom some socio-economic indicators receded throughout the transition. But this is not the whole story. The declining standard of living was doubled by the emergence of nationalist and xenophobic movements in which Roma were attacked, their houses have been burned and some of the attacks have even resulted with casualties. The cases of Hădăreni and Kogălniceanu are relevant for the above said. Roma were constantly imagined as the 'Other', a foreign minority, and made scapegoats for the failure of transition to market economy (Crowe 1999; Crowe 2008; Verdery 1993). This mob and institutional violence against Roma due to their mass unemployment did not remain unnoticed. Various inter-governmental organizations, from the European Union (EU), Organization for Security and Cooperation in Europe (OSCE), Council of Europe (CoE), development agencies such as World Bank and the United Nations Development Programme (UNDP) and human rights organizations embraced the Romani case and declared it as a "human emergency".

The protection of Roma minority in the region became one of the key objectives of the Copenhagen criteria on which future Member States had to comply. The document stated, inter alia, that EU candidate countries must ensure a functioning market economy, the stability of democratic institutions, the rule of law, respect for human rights and to ensure the protection of minorities rights (CoE 1993b). In the same year, the Council of Europe will define Roma as a European minority. In Recommendation 1203, the Council stated that "living scattered all over Europe, not having a country to call their own, they are a true European minority" (CoE 1993a). IGOs will henceforth refer to the Roma as a European minority. When asking who the Roma are, the World Bank will respond in one of its extensive report with 'the largest and vulnerable minority in Europe' (2005: 3). Alongside with extensive reports, this IGOs have developed their own centers of expertize. OSCE established a contact point for Roma and Sinti within the Office for Democratic Institutions and Human Rights in 1994 and established an adviser on Roma and Sinti issues in the OSCE in 1998 (OSCE 2008). Council of Europe awarded a coordinator job on Roma issues in 1994 and set up a group of experts on Roma, Gypsies and Travellers in 1995, later renamed MS- S - Rom (Committee of Experts on Roma and Travellers) and initiated the European Roma and Travellers Forum in 2004. At the beginning of the new millennium, Roma have come in the attention of the World Bank and the United Nations through a series of reports (Ringold 2000; Ringold et al. 2005; UNDP 2002; UNDP 2005; UNDP 2006; WB et al. 2002b; Revenga et al. 2002a) But IGOs were not the only institutions who assumed the Europeanization on Roma's minority status. Various NGOs, Open Society Institute, international and transnational NGOs (INGO) such as the European Roma Rights Center, International Minority Rights Group, the European Centre for Minority Issues or networks of these associations and Roma NGOs: - the European Information for Roma and the European Roma Grassroots Organizations that joined in advocacy networks and transnational activism - particularly EU Roma Policy Coalition - asking new coherent policies for Roma in the EU and was influential in developing new strategies to improve the situation of Roma during the period 2011-2020.

This European institutions, development agencies and non-governmental have explicitly called for the inclusion of Romani actors in the policy devised for them. This active inclusion would empower the Romani minorities, develop their communities and improve their standard of living. I do not intend to say that the rising activism at national and transnational level brought substantial benefit for Roma communities. Their implication in policy outputs and the work with Roma communities have ambiguous results. On the one hand, local and national Romanian and Romani NGOs were financed by the IGOs and the INGOs which raised awareness and visibility of Roma's problems at local and national level. These projects not only raised awareness but educated a Romani elite giving them the skills and expertise to support their participation in the processes of decision-making or advocacy (Ram 2011). One example can be given here. During the first half of the ' 90 , when the EU launched its enlargement policies and pressured for 'protection of minorities', the EU had no minority policy. Because of the constant pressure of Romani and pro-Roma groups, as well as other advocacy groups, the EU has gradually shaped it's anti-discrimination policy, including Race Equality Directive (EC 2000c) and the Framework Convention for the Protection of National Minorities (CoE 1995) On the other hand, Roma continue to be marginalized, discriminated against, politically underrepresented, with a higher probability of being unemployed, not having access to public services - education, health , housing - compared with the majority population.

The active involvement of Roma in the programs devised for them has to do with the new approach to governance developed in the second half of the " 90 s that had an impact on minority policies at European and national level. In this context, minority governance refers to a set of tools and methods that facilitate the participation of minorities in society to prevent and / or reduce conflicts between minorities and the majority population, to institutionalize the protection 
of minorities, so minorities themselves can become agents and representatives in decision-making processes that concern them directly (van Baar 2011a: 9).

The rising international NGOs / local / national dealing with Romani affairs and the transformation of the governance agenda of international institutions (UNDP, World Bank, OECD or EU) are closely interrelated. The emergence of a development agenda focused on social, civic and human dimensions and the development of civil society as part of the governance process are closely intertwined. The increasing number of development programs focused more on the involvement of civil society are part of the new non-governmentalism approach (Lewis 2005). This new approach is based on the criticism to the development programs guided by national governments over several decades. These nongovernmental ways to govern a population issues are an alternative to previous programs or schemes that have been implemented by the centralized state, as in socialism, or earlier neoliberal programs of structural adjustment. Governments involved in the development industry, international and European institutions have adopted this non-governmental governing agenda, often specified in the funding requirements (Lewis 2005).

\section{The governance turn}

The active inclusion of Romani actors in the programs devised for them, supported by European and international governance institutions has to do with the new approach to governance developed from the second half of the '90s that had an impact on minority policies at European level. In this context, minority governance refers to a set of tools and methods that facilitates the participation of minorities in society to prevent and / or reduce conflicts between minorities and the majority population, to institutionalize the protection of minorities, so the minorities themselves become agents and representatives in decision-making processes that concerns them directly (van Baar 2011a). Governance theories have emerged as a critical stance towards social science and political theories that places the nation state and its apparatus as the only authority in the governance structures and social relations. Although an analysis of the modern state - like that of Theda Skocpol, Peter Evans and Dieter Reuschemeyer (1985) - as the only container of political power with a push towards centralization, regulation and control seems tempting, political systems in the postmodern era cannot be understood simply in terms of statehood. Non-state authorities, expert systems, NGOs and quasi-governmental organizations, informal networks or formal self-governing communities or even transnational undermine or compete with the centralization of state power (Cotoi 2011; Rose \& Miller 1992). Governance is conceptualized in this sense as a new pattern or government structure and as a process of coordination through self-government networks and partnerships that occur at supra-state or sub-state level (local and regional).

As a consequence of dispersal of state power, at the EU level we are witnessing the appearance of multi-level governance, where different entities from the European Union, the Organization for Security and Cooperation in Europe and the Council of Europe, national governments, municipalities, advocacy networks and NGO networks have developed policies and instruments through action plans at European, national, regional and local (community) level. Multi-level governance approach seeks to answer two key questions, namely how and at what level can the most appropriate instruments be developed to foster minority participation, empower communities and improve their socio-economic situation, and prevent political and civil conflicts between minorities and the majority population (van Baar 2011a: 9).

This reconceptualization of minority governance starts from two general assumptions, one descriptive and the other prescriptive (normative). The normative assumption refers to the appearance of 'good governance', which implies the existence of bad governance used less often. Governance is considered good when the role of the state is minimized, reduces the size of the administrative and political apparatus, introduces a new type of public management - low cost and effective at the same time. Overall, good governance has changed the politics role in managing the economy and society in the sense of a reduced governance with the exercising of political power by creating programs and policies, rather than by delivering services (Rose 1999: 16). One of the institutions that ensures the reality that lies behind the concept of good governance is the World Bank that supports the dispersion of state power in a series of public service providers, NGOs and quasi-NGOs, auditors of public finances, coupled with the ideology human rights, rule of law, political pluralism and freedom of the press (WB 1997). Good governance encourages practices that involve dispersion or creating horizontally relationships between different actors and agencies towards democratization and sustainable forms of decision making. The concept of good governance has influenced the integration policies in the European Union and led to the numerous strategies and requirements of advocacy networks and actors involved in the elaboration / implementation of public policies, including minority policies. The White Paper on governance, developed by the European Commission, for example, links practices of good governance that enhance openness, participation, accountability, effectiveness and coherence for establishing more democratic governance (EC 2001: 10) 


\section{Global governance model in minority-related affairs}

Since the beginning of the millennium, international governance organizations (UNDP, World Bank, European Union) have adopted a neoliberal trend to govern social and minority affairs through processes of decentralization, the 'outsourcing' of public services to private stakeholders, the support of 'public-private partnerships', and the mobilization of civil society agencies. This model was presented as a stimulus to make government and its structures more sustainable, democratic, efficient and also levers for minority empowerment, development and social inclusion (EC 2002; EC 2003; EC 2000a; EC 2000b; EC 2001; EC 2006; EU 2011; OSI 2011; Ringold et al. 2005; UNDP 2006; WB 2005). However, as I will try to show, this model of governance raises some issues. Studies focusing on neoliberal governance consider the issues that it wishes to address as external to the discourse about them. In other words, the emergence of discourse and studies of governance should be seen as a symptom of the changing patterns and processes of government and not as a direct result thereof. So what is the rationality of practices and discourses behind the growth of governance studies at European or concepts such as good governance? The practical questions that I am trying to answer is why did the Roma appear on the human development agenda of UNDP, the social inclusion agenda of EU or the minority rights and human security agenda of OSCE?

In the early 1990s, non-governmental organizations and civil society more widely were linked with new ideas, practices and concepts to improve democracy, reduce inter-ethnic conflicts, underdevelopment, poverty and socioeconomic exclusion. Peace and prosperity could not be understood only in terms of economic or structural, but also through the quality of state institutions. This transformation was observed by former chief economist of the World Bank, Joseph Stiglitz as such (2003: 78; 85; 86; 88):

Development represents a transformation of society [...] has profound implications not only for what national governments and international agencies do, but also for the way in which they proceed-how they engage, for instance, in participation and partnership, particularly with market-related institutions and civil society [..] This vision needs to include a view of the transformation of institutions, the creation of new social capital and new regulatory or incentive mechanisms [..] Poor countries-are resource-constrained. While there are many pressing needs, it is imperative that any development strategy should set priorities. Not only must there be co-ordination of different agencies within and among levels of government: there must be co-ordination between the private sector and the public, and among various parts of the private sector [...] Key ingredients in a successful development strategy are ownership and participation. By involving these groups, the process of strategy formulation may be able to elicit the commitment and democratic involvement that is necessary for development to be socially acceptable and sustainable.

This human development approach in the development policies represents an important shift form the older paradigm on development, growth and inclusion. Thus, the pattern of development in Western Europe after the Second World War was that of a capitalist development and technology (with its equivalent in South-East industrial and technological development but under the direction of an authoritarian state). The reduction of poverty in this system was that of 'economic growth based on investment and the application of science and technology [Poverty reduction and economic growth] will be achieved through planning, state intervention and economic redistribution'(Duffield 2001: 23). Until 1980, in development programs, the unit of analysis was nation-states and national economies. At international level, the unit of analysis and comparison was also the nation-state and inter-state conflicts. But, due to the shifts in political economy and the pressures on nations-states sovereignty by the emergence of the international structures and regimes, that has gone hand in hand with what many analysts have called 'globalization' (Appadurai 1996), security and development agendas are being reconceptualized. Conflicts are no longer intra-state but inter-state, and affect ethnic, religious or migrants groups. While addressing security, new development programs embrace a people-centered approach, which prioritizes the development of individuals rather than states:

Under the banner of sustainable development, formal development practice embraced a human, people-centered focus that not only prioritized the development of people ahead of states; it also decoupled human development from any direct or mechanical connection with economic growth. The move towards sustainable development was a move away from an earlier dominance of state-led modernization strategies based on the primacy of economic growth and assumptions that the underdeveloped world would, after passing through various stages, eventually resemble the developed. Rather than economic growth per se, a broader approach to development emerged based on aggregate improvements in health, education, employment and social inclusion as an essential precursor for the realization of market opportunity (Duffield \& Waddell 2006: 5)

UNDP has also integrated its human development approach with minority rights during the 1990s as a way to improve the access to social, economic, cultural and political rights: 'UNDP advocates the realization of human rights as part of sustainable human development, an approach that places people at the center of all development activities. The central purpose is to create an enabling environment in which all human beings lead secure and creative lives. Sustainable human development is thus directed towards the promotion of human dignity-and the realization of all human rights, economic, social, cultural, civil and political' (UNDP 1998). 
No doubt that this policy responses from the IGOs during the 1990 was due the increasing ethnic conflict in the Eastern Europe. But the problematization of their inclusion was no longer a matter only of state policies but rather it had to do with a weak and underdeveloped civil society and to insufficient development of human and social capital, which became explanatory variables in new approaches to poverty and underdevelopment. Mobilizing civil society has become an important pillar on IGOs agenda after the fall of the socialist regime, which had to be revived, supported, encouraged, and developed through training and capacity building programs. The permanent focus by governing institutions (EU, World Bank) on the mobilization of civil society and involvement of NGOs or advocacy groups is based on the rationale that the latter will not only be involved in developing and implementing development strategies but will enable civil society and increase democratization from bottom-up (Weiss 2000). As the European Commission has put it (EC 2000b: 2; 5; 6):

NGOs can make a contribution to fostering a more participatory democracy both within the European Union and beyond [..] The contribution of NGOs is particularly important in tackling social exclusion and discrimination, protecting the natural environment, and the provision of humanitarian and development aid. NGOs have been chosen as partners because of their specificity coupled with their expertise and technical capacity

Returning to global governance agendas, we have seen in the last 20 years a continuous expansion of non-governmental organization which pretends to represent Roma affairs. Some have referred to this event as 'Roma industry' (e.g. Ram 2011). In a research conducted at the end of the ' 90 s, a report on Roma projects in Romania - itself financed by the EU's PHARE program and published by a Romanian NGO that works on Roma issues - found 1013 projects aimed at Roma communities implemented by 519 organizations from 1990 to 2000. NGOs (associations and foundations) implemented at least 79 per cent of these projects (other implementers being primarily government institutions). While no more than 20 projects per year were implemented from 1990 to 1992, there were approximately 300 projects in 2000 (Bădescu 2001: 3637; Anăstăsoaie \& Tarnovschi 2001: 181). It is useful to say that the first decade after the fall of socialism was characterized by a heterogeneous implication by the IGOs and the international non-governmental organizations and a lack of clear strategies by the Romanian government (Cace et al. 2005; Dediu 2007). Over time, the EU and Open Society Foundation have financed activities to improve the situation of Roma and to build the capacity and advocacy skills of Romani NGOs. The results of this development approach are still ambiguous. Some authors have already started to discuss the NGOisation of Romani movement and politics, which during the last 25 years has been fragmented due to different scopes, community needs, framing identities and sources of financing the movement (Kovats 2003; McGarry 2010; Rostas 2009; Stubbs 2007; Barany 1998; Barany 2002). Due to the conditions of financing the Roma related projects by the IGOs, the more 'successful' NGOs have turned into professionalized and bureaucratic ones, which limited the "dynamics and flexibility of civil society" (Rostas 2009: 170) in finding the complex answers to the multifaceted problems of marginalized Romani groups.

\section{Conclusion}

The situation of Roma since the fall of socialism is a paradox. On the one hand, many organizations, international governing organizations (IGOs) such as the European Union (Council of Europe, European Commission, European Parliament), the Organization for Security and Cooperation in Europe, the World Bank and the United Nations (UNDP, UNICEF, ILO), local and international/transnational NGOs, government agencies are involved in projects for Roma to improve their situation in Europe. Roma have become the target of social inclusion programs of the European Union (EU), the Decade of Roma Inclusion - a project of the Open Society Foundation and the World Bank -, Strategies for improving the situation of Roma developed by governments in Southeastern Europe. On the other hand, Roma continue to be marginalized, discriminated against, politically underrepresented, with a higher probability of being unemployed, not having access to public services education, health , housing - compared with the majority population. What has this short essay tried to argue is that after 1989, the 'will to turn the tide' for Roma went hand in hand with a new approach to political representation and development agenda. If during Enlightenment, nation-states building and socialism, the Roma were seen as a non-European, alien group, a barrier to western civilization, which legitimated its coercive policies towards the ethnic group, after 1989 the identity of heterogeneous group, with different socio-economic conditions, cultural differences and different dialects have been Europeanized. Reconsidering Roma as a European minority has an important implication in the policies of the European institutions. Europeanization of minority representation has become a catalyst tool for empowering Roma inclusion, facilitating and ensuring access to social justice and public services (van Baar 2011a). If during the last three hundred years we have witness large scales programs to improve the socio-economic situation of Roma, what is truly new after 1989 is this European effort of active social inclusion of Roma in which Roma themselves become partners in the programs tailored for them. IGOs, European institutions, local, national and international NGOs have asked the direct involvement of Roma in developing new policies that would serve them. The active inclusion would have empowered the Roma minority, improve their standard of living and contribute to the development of their communities 
The active involvement of Roma in the programs devised for them has to do with the new approach to governance developed in the second half of the ' 90 s that had an impact on minority policies at European and national level. In this context, minority governance refers to a set of tools and methods that facilitate the participation of minorities in society to prevent and / or reduce conflicts between minorities and the majority population, to institutionalize the protection of minorities, so minorities themselves can become agents and representatives in decision-making processes that concern them directly. This policy shifts was a result of the numerous attacks on Roma and inter-ethnic conflicts that Romania faced during the beginning of the ' $90 \mathrm{~s}$. Instruments and methods had to be devised so the number of conflicts would reduce. Therefore we have witnessed a number of policy documents and instruments, of which we could mention the Race Equality Directive and the Framework Convention for the Protection of National Minorities, with a large input from Romani groups, activists and NGOs.

To put in practice its rationale of governing, the IGOs have launched large scale programs in Eastern Europe to transform institutions and practices of governance. Since the beginning of the millennium, IGOs have launched a new governance agenda of social and minority affairs through processes of decentralization, the 'outsourcing' of public services to private stakeholders, the support of 'public-private partnerships', and the mobilization of civil society agencies. This model was presented as a stimulus to make government and its structures more sustainable, democratic, efficient and also levers for minority empowerment, development and social inclusion. However, this model of governance raised some issues. Studies focusing on neoliberal governance consider the issues that it wishes to address as external to the discourse about them. In other words, the emergence of discourse and studies of governance should be seen as a symptom of the changing patterns and processes of government and not as a direct result.

Therefore it is important to analyze why did the Roma appear on the human development agenda of UNDP, the social inclusion agenda of EU or the minority rights and human security agenda of OSCE as they did? To answer these questions I have argued that after 1989, we are witnessing a different type of problematization regarding human security, human development and social inclusion. Due to the massive ethnic conflicts in the former Yugoslavia, the IGOs have started imagine the whole eastern bloc as an area of (in)security. As a consequence, the former agenda of intra-state security of OSCE has migrated towards and intra-state conflict agenda. The burst of ethnic conflicts was seen as a consequence of poverty and underdevelopment. The confluence between security and development has motivated some IGOs to devise human development and human security as a tool for conflict management. IGOs enable human and minority rights norms and conventions, such as the UN Declaration of Human Rights and the Geneva Conventions, to improve and redirect their development programs. In this line of reasoning, human security and human development are presented as "integrating human rights with sustainable development" (UNDP 1998: 181; van Baar 2011a).

This governance model had some ambiguous results. IGOs sustained financially and logistically the revival of a civil society that would take the Roma case as a site of intervention. The revival of a Romani civil society was an important variable to the pan-European effort to make them actors in the policies devised for them. Due to the different interests, needs and financing sources, the Romani movement has been very heterogeneous, leader-based, leading cu frustration from the Romani activist not being able to establish a common identity. Others have critiqued the functioning of these NGOs, who have transformed themselves in professionalized and bureaucratized NGOs, with a reduced flexibility to find complex answers to the multifaceted problems of marginalized Romani groups.

\section{References}

[1] Anăstăsoaie, V. \& D. Tarnovschi (eds.), (2001). Roma projects in Romania, 1990-2000, Cluj-Napoca: Ethnocultural Diversity Resource Center.

[2] Appadurai, A., 1996. Modernity at Large. Cultural Dimensions of Globalization, Minneapolis and London: University of Minnesota Press.

[3] Bădescu, G., (2001). A Quantitative Analysis of the Roma projects, in Roma Projects in Romania, 1990-2000, eds. V. Anăstăsoaie \& D. Tarnovschi Cluj-Napoca: Ethnocultural Diversity Resource Center, 35-68.

[4] Barany, Z., 1998. Ethnic mobilization and the state: the Roma in Eastern Europe. Ethnic and Racial Studies, 21(2), 308-27.

[5] Barany, Z., 2002. Ethnic Mobilization without Prerequisites: The East European Gypsies. World Politics, 54(3), 277-307.

[6] Cace, S., G. Duminică \& M. Preda (eds.), (2005). Evaluarea Programelor pentru Comunitățile de Romi din România, București: Agenția de Dezvoltare Comunitară "Împreună".

[7] Council of Europe, (1993a). Recommendation 1203 on Gypsies in Europe, Strasbourg: Council of Europe.

[8] Council of Europe, (1993b). European Council in Copenhaga. Conclusions of the Presidency, Copenhaga: Council of Europe. 
[9] Council of Europe, (1995). Framework Convention for the Protection of National Minorities, ed. CoE Strasbourg: Council of Europe.

[10] Cotoi, C., 2011. Neoliberalism: a Foucauldian Perspective. International Review of Social Research, 1(2), 10924.

[11] Crowe, D., 1999. The gypsies of Romania since 1990. Nationalities Papers: The Journal of Nationalism and Ethnicity, 27(1), 57-67.

[12] Crowe, D., 2008. The Roma in Post-Communist Eastern Europe: Questions of Ethnic Conflict and Ethnic Peace. Nationalities Papers: The Journal of Nationalism and Ethnicity, 36(3), 521-52.

[13] Dediu, M., (2007). Rolul instituțiilor internaționale în reformarea politicilor publice pentru romii din România, in Politici publice si administratie publica ed. F. Bondar lași: Polirom, 167-99.

[14] Duffield, M., 2001. Global Governance and the New Wars. The Merging of Development and Security, London and New York: Zed Books.

[15] Duffield, M. \& N. Waddell, 2006. Securing Humans in a Dangerous World. International Politics, 43, 1-23.

[16] European Commission, (2000b). The Commission and non-governmental organisations: building a stronger partnership, Luxembourg: European Commission.

[17] European Commission, (2000c). DIRECTIVA 2000/43/CE a Consiliului de punere în aplicare a principiului egalității de tratament între persoane, fără deosebire de rasă sau origine etnică, in 2000/43/CE, ed. E. Commission Bruxelles: Jurnalul Oficial al Comunitătilor Europene.

[18] European Commission, (2001). European Governance. A White Paper Bruxelles: European Commission.

[19] European Commission, (2011). An EU Framework for National Roma Integration Strategies up to 2020, Bruxelles: European Commission.

[20] European Parliament, (2005). European Parliament Resolution on the Situation of the Roma in the European Union, Bruxelles: European Parlament.

[21] European Parliament, (2008). European Parliament Resolution on a European strategy on the Roma, Bruxelles: European Parliament.

[22] European Union, (2003). European Union support for Roma communities in Central and Eastern Europe, Brussels: Enlargement Information Unit.

[23] Evans, P., D. Rueschemeyer \& T. Skocpol (eds.), (1985). Bringing the State Back In, Cambridge: Cambridge University Press.

[24] Flasikova-Benova, M., H. Swoboda \& J. M. Wiersma (eds.), (2011). Roma: A European Minority. The Challenge of Diversity, Bruxelles: S\&D Group.

[25] Kovats, M., (2003). The politics of Roma identity: between nationalism and roma destitution, in Open Democracy UK, $1-6$.

[26] Lewis, D., (2005). Individuals, Organisations, and Public Action, in A Radical History of Development Studies, ed. U. Kothari London: Zed Books, 200-21.

[27] Liégeois, J.-P. \& N. Gheorghe, (1995). Roma/Gypsies: A European Minority, London: Minority Rights Group.

[28] McGarry, A., 2008. Ethnic Group Identity and the Roma Social Movement: Transnational Organizing Structures of Representation. Nationalities Papers: The Journal of Nationalism and Ethnicity, 36(3), 449-70.

[29] McGarry, A., 2010. Who Speaks for Roma? Political Representation of a Transnational Minority Community, New York: The Continuum International Publishing Group Inc.

[30] McGarry, A., 2011a. The Roma Voice in the European Union: Between Belonging and Transnational Identity. Social Movements Studies: Journal of Social, Cultural and Political Protest, 10(3), 283-97.

[31] McGarry, A., 2011b. The dilemma of the European Union's Roma policy. Critical Social Policy, 32(1), 126-36.

[32] Mirga, A. \& N. Gheorghe, (1997). The Roma in the Twenty-First Century: a Policy, Princeton, New Jersey: Project on Ethnic Relations.

[33] Organisation for Security and Cooperation in Europe, (2008). Implementation of the Action Plan on Improving the Situation of Roma and Sinti Within the OSCE Area, Warsaw: OSCE/ODIHR.

[34] Ram, M., 2011. Roma advocacy and EU conditionality: Not one without the other? Comparative European Politics, 9(2), 217-41.

[35] Revenga, A., D. Ringold \& W. Tracy, (2002a). Poverty and Ethnicity. A Cross-Country Study of Roma Poverty in Central Europe, Washington DC: The International Bank for Reconstruction.

[36] Ringold, D., (2000). Roma and the Transition in Central and Eastern Europe: Trends and Challenges, Washington: The International Bank for Reconstruction and Development.

[37] Ringold, D., M. Orenstein \& E. Wilkens, (2005). Roma in an Expanding Europe: Breaking the Poverty Cycle, Washington: International Bank for Reconstruction. 
[38] Rose, N., 1999. Powers of Freedom. Reframing Political Thought, Cambridge: Cambridge University Press.

[39] Rose, N. \& P. Miller, 1992. Political Power beyond the State: Problematics of Government. The British Journal of Sociology, 43(2), 173-205.

[40] Rostas, I., (2009). The Romani Movement in Romania: Institutionalization and (De)mobilization in Romani Politics in Contemporary Europe. Poverty, Ethnic Mobilization and Neoliberal Order, eds. N. Sigona \& N. Trehgan UK: Macmillan Publishers Ltd, 159-85.

[41] Stiglitz, J., (2003). Towards a New Paradigm of Development, in Making Globalization Good: The Moral Challenges of Global Capitalism, ed. J. H. Dunning Oxford: Oxford University Press, 76-107.

[42] Stubbs, P., (2007). Aspects of Community Development in Contemporary Croatia: Globalization, Neoliberalisation and NGO-isation, in Revitalising Communities in a Globalising World, ed. L. Dominelli UK: Ashgate, 161-74.

[43] UNDP, (1998). Integrating Human Rights with Sustainable Development. A UNDP policy document, New York: United Nations Development Programme.

[44] UNDP, (2002). Avoiding the Dependency Trap. The Roma in Central and Eastern Europe, Bratislava: United Nations Development Programme.

[45] UNDP, (2005). Faces of Poverty, Faces of Hope. Vulnerability Profiles for Decade of Roma Inclusion countries, Bratislava: United Nations Development Programme.

[46] UNDP, (2006). At Risk: Roma and the Displaced in Southeast Europe, Bratislava: UNDP.

[47] van Baar, H., 2011a. Minority Representation, Memory and the Limits of Transnational Governmentality, Amsterdam: University of Amsterdam.

[48] van Baar, H., (2011b). Reflections on Contemporary Romani Minority Governance in Europe: The Double Bind, in Social Inclusion of the Roma in Europe: Challenges, Solutions Budapest.

[49] Verdery, K., 1993. Nationalism and National Sentiment in Post-socialist Romania. Slavic Review, 52(2), 179203.

[50] World Bank, (1997). World Development Report. The state in a changing world New York: Oxford University Press.

[51] World Bank, F. Space, Ineko \& OSI, (2002b). Poverty and Welfare of Roma in the Slovak Republic, Washington: World Bank.

[52] Weiss, T., 2000. Governance, good governance and global governance: Conceptual and actual challenges. Third World Quarterly, 21(5), 795-814.. 